\title{
$P-387$ ヒト蕉海綿体の原線維と弾性線維の加粭变化
}

岩手医科大学

梶川恒雄、萬谷嘉明、金井秀明、徳永英夫、黑澤 尚、久保 隆

【目的】勃起組織である陰基海綿体は、主として膠原線維と弾性:線維からなる白膜で囲まれ、同様の線 維成分からなる除茎海綿体の小柱（海綿体洞の壁）には豊富な平滑筋と自律神経線維が認如られる。先 に私たちは陰茎海綿体の平滑筋や自律神経線維が高㱓者で有意に減少していることを報告したが、今回 は、膯原線維と弾荘線維が加龄によりどのように变化しているのか検誩した。【対象と方法】剖検時に 得たヒト陰茎93例を对象とした。このうち63例は、アザン・マロリー染色およびアルデヒド・フクシ

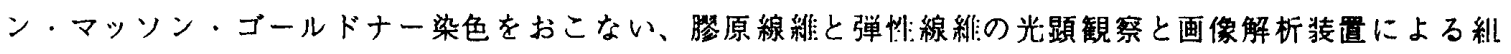
織定量的解析をおこなった。残る30例のうち20例は10\% NaOH溶液に7ー14日間浸軟处理（室温）した のちに、残りの10例は $25 \% \mathrm{KOH}$ 溶液で12分間加温处理 $\left(60^{\circ} \mathrm{C}\right)$ したのちに、導䉓染色、凍洁乾燥、白 金蒸着し、走查電顕で観察した。標本の一部は人工勃起状態で固定し作製した。【結果】䊶織定量的解

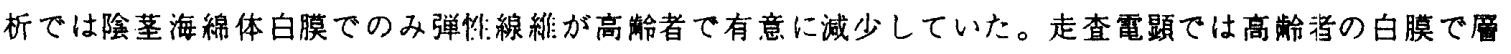
板を形成する膠原線維間の結合が悪くなり層板がバラバラに解蜼しているのが琹められた。人工勃起状 態の白膜では層板（特に中間層）の伸展が悪くなっていた。弾性線維も高龄者の陰茎海繶体白膜では線

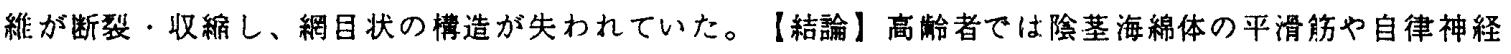
線維の隇少に加之、陰茎海綿体白膜の弾慛線維が減少していることが明らかとなった。この減少は走查 電顕による観察から弾㠼:線維の断裂・収縮を反映しており、陰茎海綿体白膜の層板の膠原線維:間の解離 とともに高龄者における勃起維持の障害に深く関与していると思われた。

\section{$P-388$ 社会的ストレスにより意起される性行動寒の発現機序}

\author{
愛媛大学医学部泌尿器科1)、愛媛大学医学部附属実験実習機器センター?!)

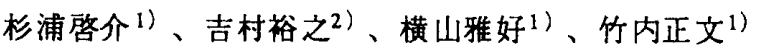

く目的〉これまでに、演者らは、社会的ストレスとして種内閭争に着目し、反復して敗北を経験させ た雄マウスが発情期の崔マウスに対して性行動を示さなくなることを報告してきた。また、このような 性行動障害に対して腷内のセロトニンおよびドーバミン受容体に親和性を有するリスライドが改善効果 を示すことも見いだしている。今回、演者らは、性行動障害の脳内機序を明らかにする目的て、以下の 実験を行った。く方法>実験にはICR系マウスを用いた。的8週龄の焳雄マウス一対を的5避間同居飼育 し生活居住域を確立させたのち、そこへ雄のみで群居飼育したマウスを侵入させることにより闑争を惹 起した。居住マウスから侵入マウスが咬みつかれる回数を1日20回に統制し、連秸5日間敗北を経験さ せた。敗北を経験する前日および最後に敗北を経験した翌日、発情期の雌マウスと10分間戈遇させた。 すべての行動は高感度ビデオシステムに収録し、録画画面を観察しながらエベントレコーダーを操作す ることにより行動解析を行った。セロトニン関連薬物として p-chlorophenylal anine (PCPA), p-chloroamphetamine (PCA), methysergide, 8-OH-DPATを用いた。く結果>PCPA $(50,100,150 \mathrm{mg} / \mathrm{kg})$ は、対 照群に比へ用量依存的に有意な性行動の改善を示した。PCAは投与後5日目において有意差はなないもの のコントロール群に比べ改善傾向を示した。一方、methysergide，8-OH-DPATは性行動を改善する効果 が認められなかった。く結語＞以上の結果より、脳内セロトニン含量を減少させるような菲物により社 会的ストレスによる性行動障害は改善されることが判明した。脳内ドーパミン作動神経系に作用する1dopaやapomorphineの効果についても報告する。 